\title{
Responsabilidade do Estado por Atos Judiciais*.
}

\author{
Cretella Júnior \\ Catedrático de Direito Administrativo na \\ Faculdade de Direito da Universidade de \\ S. Paulo.
}

Sumário: 1. Atos do Judiciário. 2. Responsabilidade judiciária. 3. $\mathrm{O}$ ato jurisdicional danoso. 4. $\mathrm{O}$ ato não jurisdicional danoso. 5. Direito positivo. 6. Doutrina. 7. Argumento da "soberania". 8. Argumento da "coisa julgada". 9. Primeiras decisões brasileiras. 10. Sentido da jurisprudência atual. 11. Síntese geral. 12. Conclusões.

1. Ao Poder Judiciário está afeta, por excelência, a edição dos atos denominados jurisdicionais. Trata-se dos atos formais ou orgânicos, manifestações típicas e inconfundiveis daquele poder, atos que, a final, se concretizam na sentença judiciária, momento culminante da atividade jurisdicional do Estado.

*. ARdant, La responsabilité de l'État du fait de la fonction jurídictionelle, 1956; WALINe, Droit administratif, $9^{7}$ ed., 1963, pág. 909; LAUBADÈre, Droit administratif (Traité), $3^{\text {a }}$ ed., 1963, vol. II, pág. 630; RIVEro, Droit administratif, $3^{7}$ ed., 1965, pág. 267; VEDEL, Droit administratif, $3^{7}$ ed., 1964, pág. 312; BonNard, Précis, 1935, pág. 49 e Le contrôle, 1934, pg. 19; ZANOBINI, Corso, 6* ed., 1950, vol. I, pág. 277; ENRIQUe SAYagués LASo, Tratado, 1953, vol. I, pág. 671; Gelsi BIDART, Responsabilidade dos juízes no direito uruguaio, trad., em Revista de Processo Civil, S. Paulo, 4..$^{\circ}$ 1964, pág. 28. 
$\mathrm{O}$ ato jurisdicional não esgota, entretanto, tôda a atividade do poder judiciário, embora seja, repetimos, a manifestação inerente àquele poder. É que, ao lado da função jurisdicional, tendente à aplicação da lei ao caso concreto, sempre que ocorre contestação, existe outra função, de natureza administrativa, voluntária, graciosa ou não contenciosa, desenvolvida de maneira intensa no âmbito do poder judiciário.

Dêsse modo, os atos do poder judiciário ou são atos jurisdicionais, decorrentes da correspectiva função jurisdicional, ou são atos administrativos, oriundos de função judicial, lato sensu, que é gênero do qual as duas outras funções, a contenciosa e a voluntária são espécies.

$O$ ato jurisdicional supõe a contestação de uma pretensão. A contestação produz perturbação na vida social. Èsse desequilíbrio precisa ser corrigido.

"Numa sociedade que funcionasse de modo ideal, com regime jurídico perfeito e membros compenetrados do mais alto sentimento cívico e do sentimento da boa fé, as contestações não se concretizariam. Como, porém, tais condições estão longe de serem atingidas, é preciso levar em conta o fenômeno da contestação, sempre que tal ocorre, e procurar os meios de resolvê-lo tão corretamente e tão ràpidamente quanto possivel. Eis a finalidade da função jurisdicional, função que se realiza por meio do ato jurisdicional" (Duez E DeBeyre, Traité de droit administratif, 1952, pág. 196).

Se os fenômenos jurídicos se resumissem em dois apenas - os fenômenos de formação e os de realização do direito - as funções específicas e distintas do Estado seriam a legislativa e a administrativa, visto que tais funções esgotariam todos os fenômenos de formação e de realização do direito. Nesse caso, a função jurisdicional de modo algum seria autônoma e com características próprias.

Entretanto, além dos fenômenos citados, de formação e de realização do direito, ocorre ainda um outro fenômeno, 
que é o fenômeno contencioso, em razão do qual a função jurisdicional é função autônoma e distinta, materialmente, das outras funções do Estado.

Com efeito, a situação contenciosa é fato anormal, que não deve manter-se, que precisa. desaparecer. Assim o exige a paz social. O objetivo precípuo da função jurisdicional é a intervenção tendente a eliminar tôda espécie de incidentes, consubstanciados numa contestação, que se interpõem no processo normal e contínuo da formação e da realização do direito (Roger Bonnard, Précis de droit administratif, 1934, págs. 49-50).

2. Segundo alguns autores, o problema da responsabilidade do Estado em conseqüência dos serviços judiciários seria questão estranha ao direito administrativo, visto tratar-se de serviços não administrativos (Waline, Droit administratif., 9. a ed., 1963, pág. 909; RIvero, Droit administratif, 3.a ed., 1965, págs. 267-268), mas estudam o tema, tão só, porque tradicionalmente assim se procedeu, há muito.

Particularmente complexo e difícil (Laubadère, Traité, $3 .^{\mathrm{a}}$ ed., 1963, vol. II, pág. 630 e VEDEL, Droit administratif. $3 .^{\mathrm{a}}$ ed., 1964, pág. 313) é o problema da responsabilidade do Estado em decorrência do exercício da função jurisdicional, mas não obstante tal complexidade precisa ser enfrentado, mesmo porque se trata de assunto pertinente ao direito administrativo, quer o dano aos administrados advenha do próprio ato jurisdicional, quer emane - e aqui, então, não há a menor dúvida — das atividades não jurisdicionais (atos da jurisdição voluntária e atos administrativos do Judiciário) exercidos no âmbito do Poder Judiciário.

Há o dano, há o prejudicado. Indagar-se-á do responsável pelo dano. Se o Estado, direta ou indiretamente, é causa eficiente do dano, estamos diante de responsabilidade pública, regida por princípios publicísticos. $\mathrm{E}$ não 
interessa, para efeitos de responsabilização pública, se o poder público é o Executivo, o Judiciário ou o Legislativo.

Dêsse modo, reivindicando para o campo do direito administrativo o estudo da responsabilidade civil do Estado, em decorrência dos prejuízos causados pelo serviço judiciário, em qualquer de suas modalidades, ressaltamos, com Chrovenda, repetido por Francisco Campos, que "o juiz é o Estado administrando a justiça; não é um registo passivo e mecânico de fatos, em relação aos quais não o anima nenhum interêsse de natureza vital. Não lhe pode ser indiferente o interêsse da justiça. Êste é o interêsse da comunidade, do povo, do Estado, e é no juiz que tal interêsse se apresenta e personifica" (Código de Processo Civil, exposição de motivos).

Realmente, o serviço judiciário é, antes de serviço público. Ora, o serviço público danoso, em qualquer de suas modalidades, é serviço danoso do Estado. Por que motivo excluir, por exceção, o serviço público judiciário, do gênero serviço público geral?

3. Ao passo que para o serviço público, em geral, vigora o princípio da responsabilidade pública, para o serviço público judiciário prevalece o princípio da irresponsabilidade (Laubadène, Traité, 3. ${ }^{\mathrm{a}}$ ed., 1963, vol. II, pág. 630; Waline, Droit administratif, $9 .^{\mathrm{a}}$ ed., 1963, pág. 909), salvo exceções.

A atividade ou função jurisdicional manifesta-se, em essência, pelo julgamento ou ato jurisdicional. $\mathrm{O}$ ato jurisdicional, climax do funcionamento dos serviços judiciários, pode produzir danos os mais variados, entre os quais, o mais grave é o êrro judiciário. 0 êrro judiciário implica a própria negação da justiça, a não ser que possibilite, no devido tempo, a respectiva reparação.

Podem as vítimas do êrro judiciário, no campo criminal, sofrer penas privativas da liberdade e passar no cárcere durante muitos anos. Podem, em alguns sistemas 
jurídicos, sofrer, inclusive, a pena capital, ou prisão perpétua, casos em que os familiares da vítima têm o direito de pleitear indenização, em juízo. Além dêsses casos extremos, que não são hipotéticos, há outras hipóteses de detenções preventivas, que se prolongam abusivamente; de processos que terminam pelo arquivamento, mas que deixam mácula irreparável no crédito ou na reputação de uma pessoa. Quem será responsabilizado pelo prejuízo pecuniário e moral (êste sendo, inúmeras vêzes, causa daquele), ocasionado pelo mau funcionamento dos serviços judiciários? (Waline, Droit administratif, 9. ${ }^{\mathrm{a}}$ ed., 1963, págs. 909-910).

No caso do prejuízo causado por ato jurisdicional, consubstanciado na sentença, a responsabilidade do Estado esbarra contra vários obstáculos, notadamente o da presunção da verdade legal (VedeL, Droit administratif, $3{ }^{a}$ ed., 1964, pág. 313; RIvero, Droit administratif, $3 .^{a}$ ed., 1965, pág. 268; Waline, Droit administratif, 9. ${ }^{2}$ ed., 1963, pág. 909; Laubadère, Traité, 3. ${ }^{2}$ ed., 1963, vol. II, págs. 630-631), que se liga ao da res judicata. Ora, a res judicata pro veritate habetur, trazendo em si a presunção da verdade jurídica, para a qual convergem todos os atos do julgamento.

o princípio da irresponsabilidade do Estado por ato jurisdicional sofre uma exceção, no caso do êrro judiciário, apontado mediante revisão que, levada a efeito e proclamando a inocência do acusado, possibilitará a responsabilidade civil do Estado, por perdas e danos.

Se o julgamento não chegou ao fim, o prejudicado não tem ainda o direito de pleitear indenização, porque vários recursos estão à sua disposição e não se concretizou o dano.

Afora o êrro judiciário, que acarreta a responsabilidade patrimonial do Estado, as outras duas hipóteses conduzem a um verdadeiro dilema, invocado pelos adeptos da irresponsabilidade do Estado, em virtude do ato jurisdicional: ou o julgamento continua e a parte, diante da ausência de 
condenação definitiva, mesmo sofrendo danos não tem direito a indenização alguma, ou o julgamento chegou ao fim, culminando com a condenação e a parte, mesmo inocente, não pode pleitear indenização, visto que esbarrará com a imutabilidade da coisa julgada.

Encerrar a vítima do êrro judiciário, ou, de modo mais geral, de prejuízo causado pelo mau funcionamento do serviço da justiça, num tal dilema, é solução por demais simplista. É um sofisma. Com efeito, a possibilidade de interpor uma série de recursos contra a indenização injusta, proferida em primeira instância, não impede que efeitos danosos já se tenham feito sentir: reputação, honra, crédito, privação da liberdade (Waline, Droit administratif, 9. ${ }^{\mathrm{a}}$ ed., 1963, pág. 910 ).

Por outro lado, não se deve pretender reduzir todos os casos em que o mau funcionamento da justiça pode causar prejuízo ao caso mais espetacular do êrro judiciário. Simples incriminação pode ser suficiente para destruir o crédito de um negociante, a reputação do incriminado. Enfim, é inexato sustentar que a autoridade da coisa julgada seja inatacada, de modo absoluto. A revisão é sempre possível, quer em matéria civil, quer em matéria penal (Waline, Droit administratif, 9. a ed., 1963, pág. 910).

A reparação do êrro judiciário pode ser tentada pelo condenado, configurando uma das hipóteses da responsabilidade civil do Estado, como decorrência de ato jurisdicional falho, concretizado em êrro.

Os exemplos são raros, mas existem. Na França, o caso do oficial Alfred Dreyfus, acusado e condenado por espionagem injustamente (1894), mais tarde recebendo a concessão da graça (1899) e, finalmente, a reabilitação (1906), depois de violenta campanha de revisão (1897-1899), desvirtuada por paixões político-religiosas, ficou famoso como exemplo de êrro judiciário.

Em nossos dias, depois da segunda guerra mundial, uma senhora francesa, acusada de colaboracionista durante 
a ocupação alemã, foi condenada, em 1945, a trabalhos forçados, degradação nacional e confisco dos bens, mas, em 29 de fevereiro de 1956, o tribunal permanente das fôrças armadas de Bordéus, em pedido de revisão, considerou-a inocente, condenando o Estado a pagar-lhe a indenização de cinco milhões de francos (Waline, Droit administratif, 9. ${ }^{a}$ ed., 1963, pág. 910).

Além do êrro judiciário, há casos de ações movidas contra magistrados, em virtude de dolo, concussão, morosidade nos trabalhos (LAubadère, Traité, $3 .^{\mathrm{a}}$ ed., 1963, vol. II, págs. 631 e 650; Rrvero, Droit administratif, 3.a ed., 1965, pág. 268; Waline, Droit administratif, 9. ${ }^{a}$ ed., 1963, págs. 910-011), configurando a responsabilidade, motivada por falhas nos serviços judiciários, em razão de casos particulares dos magistrados e funcionários. E a denominada prise $\dot{a}$ partie pela doutrina francesa (LAubadère, Traité, $3 .^{a}$ ed., 1963, vol. II, pág. 650. Cf. Lei francesa de 7 de fevereiro de 1933).

4. O ato não-jurisdicional ou ato administrativo material (bem como o ato de jurisdição voluntária), ao lado do ato jurisdicional ou ato orgânico (ou formal), constitui a denominada função administrativa ou não contenciosa do poder judiciário.

Ligam-se ao serviço judiciário atividades que não têm o caráter jurisdicional e cujas conseqüências danosas deveriam ser reguladas pela aplicação dos princípios da responsabilidade pública, como, por exemplo, operações materiais de polícia judiciária, ou atos do estado civil.

Tratando-se de atos administrativos materiais, praticados pelos magistrados (não nas vestes judicantes), por funcionários do poder judiciário, por agentes da polícia judiciária, estarão submetidos a regime jurídico diverso daquele que regula os atos jurisdicionais, inerentes, êstes últimos, à função específica do poder judiciário - à função jurisdicional. 
5. O direito administrativo brasileiro não se afasta da orientação universal, no tocante à responsabilidade do Estado por atos judiciais.

Em nosso direito, que é o sistema da jurisdição una, orientado pelo princípio una lex, una jurisdictio, a função judicial, concretizada nos atos judiciais, é gênero, de que a atividade jurisdicional e atividade administrativa (e a da jurisdição voluntária) são espécies.

Judiciais (= judiciárias) são tôdas as atividades do Poder Judiciário, específicas ou anespecíficas, sem indagação de sua natureza, contenciosa ou graciosa. Promanando do Judiciário é judicial, orgânica ou formalmente considerada. A expressão atividade judicial esgota, assim, tôdas as possibilidades funcionais do Poder Judiciário. As jurisdicionais não: são apenas parte - embora importante - das atividades judiciárias.

Mediante a edição do ato jurisdicional, o Poder Judiciário concretiza sua atividade específica, que culmina com a prolação da sentença.

Tal é a função jurisdicional, eminentemente dinâmica, expressa por atos que obedecem a determinadas formas, peculiares aos órgãos de que promanam. Daí o dizer-se que o ato formal ou orgânico do Poder Judiciário tem sua forma típica no ato jurisdicional, cujo momento máximo é a sentença. Dêsse modo, tudo que é do âmbito do Judiciário tem o caráter de função judiciária, mas função jurisdicional é uma só, tem contornos nítidos - consiste na aplicação das normas do direito objetivo a casos concretos, em virtude de uma pretensão.

$\mathrm{O}$ que pretendem as partes - a pretensão - é o critério discriminativo que separa a função jurisdicional das outras funções do Judiciário.

$\mathrm{Na}$ jurisdição contenciosa, o autor pretende que o interêsse alheio se subordine ao seu; na jurisdição não contenciosa a lei é aplicada pelo juiz, em virtude de ato jurídico dependente da aquiescência judicial. 
o Código de Processo Civil brasileiro, no artigo 121, prescreve que o juiz será civilmente responsável quando, no exercício de suas funções, incorrer em dolo ou fraude e quando, sem motivo justo, recusar, omitir ou retardar providências que deva ordenar ex officio ou a requerimento da parte, sendo que as espécies configuradas na segunda hipótese só se considerarão verificadas decorridos dez dias da notificação ao juiz, feita pela parte por intermédio do escrivão da causa.

Dolo, fraude e providência (recusada, omitida ou retardada) são as três hipóteses que esgotam, segundo o Código de Processo Civil, de 1939, tôdas as possibilidades da responsabilização patrimonial do magistrado, no exercício de suas funções.

Já a Consolidação das Leis Penais, aprovada e adotada pelo Decreto $\mathrm{n}^{\circ} 22.213$ de 14 de dezembro de 1932 , reconhecia o instituto da reabilitação e o direito do reabilitado a uma justa indenização (artigo 86).

Em casos de revisão, o Código de Processo Penal, de 1941, prevê o direito a uma justa indenização pelos prejuizos sofridos (artigo 630).

É insustentável o disposto no artigo 121 do Código de Processo Civil, principalmente depois da Constituição Federal de 1946. Pessoalmente o juiz não é responsável. Nem pode ser. Responsável é o Estado. Juiz é órgão do Estado. Estado e juiz formam um todo indissociável. Se o magistrado causa dano ao particular, o Estado indeniza, exercendo depois o direito de regresso contra o causador do dano, sem prejuízo das sanções penais cabíveis, no caso.

Sobrepôs-se o artigo 194 da Constituição de 1946 ao artigo 121 do Código de Processo Civil, revogando-o. Mesmo, porém, que não o houvesse feito, o próprio artigo 121 não subsistiria, bastando considerar-se que a relação processual não se verifica entre as partes e a pessoa física do juiz, mas entre as partes e o Estado, do qual o juiz é o representante. 
Assim também, os artigos 294, 420 e 421 do Código Civil, que falam da responsabilidade pessoal do juiz, não têm cabimento dentro da própria sistemática do Código Civil, porque se chocam com o disposto no artigo 15 , que fala em representantes. Ora, o juiz representa o Estado, no processo. É seu representante. Como, então, ser responsabilizado pessoalmente?

6. A teoria da irresponsabilidade do Estado por atos judiciais prevaleceu durante muito tempo, em nosso direito.

Escrevendo no início do século, Amaro Cavalcanti sustentava que o Estado é irresponsável por ato judicial: "Igual irresponsabilidade, coberta pela égide da soberania, se reconhece ao Estado pelos atos dos juízes e tribunais (despachos e sentenças), cuja legalidade é sempre presumida. Mesmo em casos, nos quais se dá talvez um ato ilícito da autoridade judicial, em regra, se tem decidido na mesma conformidade. No entanto, em virtude de lei recente (9 de junho de 1895), a irresponsabilidade judiciária sofrera modificação importante, admitindo-se, agora, a ação de indenização contra o Estado, em favor dos indivíduos que forem declarados inocentes pela revisão das sentenças criminais, que os tenham condenado" ( $D a$ responsabilidade civil do Estado, 1905, pág. 351).

Carlos Maximiliano defende também a tese de que "os juízes podem ser processados e punidos, livre, entretanto, - erário, de ressarcir o dano resultante das sentenças" (Comentários à Constituição de 1891, ed. de 1918, pág. 784), ou, "O Estado responde pelos prejuízos causados por funcionários seus, excetuada a magistratura, cujos erros não oferecem ensejo para uma ação contra o Tesouro" (Idem, 2. ${ }^{\mathrm{a}}$ ed., 1923, pág. 602).

Carvalho Santos sustenta que "os juizes não são prepostos, nem o Estado é comitente. Aquêles, desde o momento que são nomeados, exercitam a sua função, não como prepostos aos quais o comitente dê as suas ordens, 
mas como órgão da soberania nacional" (Código Civil Brasileiro Interpretado, 1934, vol. I, pág. 375).

Pontes de Miranda, ao comentar a Constituição Federal de 1934, defende também a irresponsabilidade da Fazenda Federal e da Fazenda Estadual pelos prejuízos decorrentes das decisões judiciárias" (Comentários, vol. II, pág. 487).

.Cirne Lima vem sustentando, há muito, que, "em princípio, os atos do Poder Judiciário, ainda que de natureza graciosa ou administrativa, não determinam a responsabilidade do Estado pelos danos, acaso dêles decorrentes" (Princípios, 4. ${ }^{\mathrm{a}}$ ed., 1964, pág. 202 e ed. de 1939, págs. 194-195).

Em 1914, Rui Barbosa pendia para a tese de irresponsabilidade do Estado por atos dos magistrados, salientando, porém, que o direito romano conhecera tal responsabilidade em caso de dolo do juiz.

Comentando o citado artigo 121, do Código de Processo Civil, Batista Martins ponderou que "tornar o juiz civilmente responsável pelos julgamentos que profere é absurdo que a doutrina jamais pôde tolerar. Nem o juiz, nem o Estado que o houver investido na função, responde pelos danos causados em conseqüência de êrro judiciário. Se assim não fôsse, o exercício da judicatura não seria possível, porque os juízes são contingentes e estão sujeitos, na apreciação dos fatos, a errar como qualquer outro mortal" (Comentários, 1940, vol. I, pág. 361).

"A irresponsabilidade do poder público, neste caso", ensinava Pedro Lessa, "é um corolário fatal da autoridade da res judicata. Ao particular lesado por uma sentença judicial só poderia ser facultada a propositura de uma ação de indenização, depois de ter esgotado todos os recursos processuais; mas, depois de esgotados todos êsses recursos, a sentença é irretratável. Reclamar do Estado uma indenização por essa decisão inalterável fôra iniciar um nôvo litígio sôbre a questão já ultimada por uma sentença passada em julgado. Conseqüentemente, só nos 
casos de revisão e de rescisão da sentença é que podem os particulares obter o ressarcimento do prejuízo infligido por uma sentença ilegal" (Do poder judiciário, 1915, págs. 164-165).

No mesmo sentido, o pensamento de Lino LEME, em obra clássica, referente à responsabilidade extracontratual (Da responsabilidade civil fora do contrato, 1917, págs. 102-103).

7. Soberania do Poder Judiciário e "Res judicata" incontrastável - eis os dois argumentos principais em que procuram apoiar-se os adeptos da teoria da irresponsabilidade do Estado em virtude dos atos judiciais danosos.

0 argumento da soberania assim se resume: o Estado é irresponsável pelos danos originados dos atos do Judiciário, porque êste exerce função que envolve a soberania, situação que o coloca acima da lei. É a soberania do Poder Judiciário que o exime da obrigação de indenizar. E exime também o Estado.

Autores estrangeiros e nacionais encarregaram-se de refutar esta colocação, mostrando a inconsistência de pretender isentar o Estado mediante a posição intocável, incontrastável, da soberania, atributo privativo de um dos podêres estatais.

"Invoca-se, primeiramente, para a jurisdição, como para a legislação, a idéia de que se acha em presença de uma manifestação da soberania, gerando a irresponsabilidade. Sabemos o que é preciso pensar a respeito dêsse verbalismo" (Paul Duez, La responsabilité de la puissance publique, en dehors du contrat, 1927, pág. 147).

"Se a soberania é uma realidade, ela não se manifesta de modo mais intenso no ato administrativo e se ela não se opõe à responsabilidade do Estado administrador, não há motivo para que se oponha à responsabilidade do Estado juiz" (LÉON DugurT, Traité de droit constitutionnel, 2. ${ }^{a}$ ed., vol. III, pág. 499). 
"Diz-se muitas vêzes", escreve Louis Rolland, "no apoio desta solução, que o exercício do poder judiciário é uma manifestação da soberania. $O$ argumento não tem valor algum. Quem diz soberania não diz necessàriamente infalibilidade e impecabilidade" (Précis, 9. ${ }^{\mathrm{a}}$ ed., 1947, pág. 371).

Citando Willoughby, o nosso Araújo Castro diz que "a soberania reside no Estado, como um atributo inerente à sua personalidade, e não em qualquer dos órgãos do govêrno, nem mesmo no conjunto dêsses órgãos, aos quais compete ùnicamente o exercício da soberania, dentro dos limites traçados na Constituição" (A Constituição de 1937, Rio, 1938, pág. 37), porque a "idéia de soberania tem, como notas características, a unidade e a totalidade" (Trтo Prates da Fonseca, Direito administrativo, 1939, pág. 217). No mesmo sentido, Queirós Lima, quando acentua que a soberania é una, indivisível e inalienável (cit. por Araúso CASTRo, pág. 37, n. ${ }^{\circ}$ ).

Como se depreende das opiniões citadas, a teoria do Judiciário soberano (e, portanto, irresponsável civilmente), é insustentável, não obstante tenha sido defendida por conceituados mestres, entre outros, para referir apenas mais dois, Meucci (Istituzioni, 3. ${ }^{\mathrm{a}}$ ed., 1892, pág. 297) e Teissier (La responsabilité de la puissance publique, 1906, pág. 27).

8. O argumento da coisa julgada fundamenta-se no brocardo clássico de UlPIANo - res judicata pro veritate habetur (D.12.2.3.1) —, confirmado pelo Código Civil francês, art. 1.351 ("A coisa julgada é tida como verdadeira"), visto que a decisão do juiz, em última instância, transforma o branco em negro e o quadrado em redondo, por trazer em si a presunção da verdade.

A irretratabilidade ou incontrastabilidade da coisa julgada, como razão suficiente para eximir o juiz - e, pois, o Estado - da responsabilidade patrimonial pelos danos 
causados em virtude da sentença judicial, tem sido apresentada por eminentes autoridades, estrangeiras e nacionais.

Teissien sustenta que "permitir a um indivíduo reclamar indenização a pretexto de que houve violação da lei é pôr em crise a coisa julgada, o que é socialmente impossível"; "admitir a responsabilidade, por motivo de erros judiciários, é afrontar o princípio fundamental, de utilidade social incontestável, gerador de segurança: a autoridade da coisa julgada" (cit. por Duez, La responsabilité de la puissance publique, 1927, pág. 147).

Bielsa, partidário desta tese, mostra que as resoluções judiciais alcançam, quando muito, a pessoa do juiz, mas não responsabilizam o Estado, porque a sentença, erigida em coisa julgada, traz em si a presunção da verdade. Em razão dêsse princípio, o ato judicial não pode ser impugnado. Em suma, o Estado não é responsável pelo ato judicial" (Derecho administrativo, 5. ${ }^{\mathrm{a}}$ ed., 1957. vol. V, pág. 24).

Pedro Lessa é categỏrico: "Já o mesmo princípio não vigora em relação aos atos do Poder Judiciário. A irresponsabilidade do poder público, neste caso, é um corolário fatal da autoridade da res judicata" (Do poder judiciário, 1915, pág. 164); "reclamar do Estado uma indenização por essa decisão inalterável fôra iniciar um nôvo litígio sôbre a questão já ultimada por uma sentença passada em julgado" (Pedro Lessa, Do poder judiciário, 1915, pág. 165).

Ninguém nega a fôrça da coisa julgada. "A irretratabilidade da coisa julgada, porque é também um princípio fundamental, peculiar a determinados atos do poder público, tornando-os insuscetíveis de revisão, impede necessàriamente que os efeitos dêsses atos sejam contrariados ou infirmados pelos de outros que sobrevenham. Este princípio, em verdade, não comporta contestação. Negá-lo será subverter a ordem jurídica com a inutilização do aparelha- 
mento da justiça" (Responsabilidade do poder público por atos judiciais, 1941, pág. 77).

Entretanto, elevar a res judicata à categoria de muralha sacrossanta, absolutamente impenetrável, é admitir a infalibilidade do julgamento humano ou a intransigência obstinada e incompreensível, mesmo diante de êrro manifesto.

"À primeira vista", escreve Paul Duez, "o argumento da res judicata impressiona, mas não resiste à análise mais profunda. Supondo-o plenamente fundado em suas bases, não chega a justificar tôdas as soluções atuais referentes à irresponsabilidade. Não é suscetível de aplicar-se a não ser aos atos jurisdicionais pròpriamente ditos, os únicos que empenham a autoridade da coisa julgada" (La responsabilité de la puissance publique, 1927, págs. 147-148).

“A indenização em virtude de êrro judiciário nem sempre é incompativel com o princípio da autoridade da coisa julgada. Bem ao contrário, há casos em que a outorga da indenização é precisamente uma homenagem a êsse princípio. Num julgamento absolutório, o indivíduo perseguido em juízo, que se beneficia com tal julgamento, reclama a indenização. Em que se verifica a violação da coisa julgada? Funda-se o reclamante, ao contrário, no julgamento liberatório para apoiar sua pretensão. A autoridade da coisa julgada só se ergue contra uma decisão judiciária que conceda indenização, deixando de lado um julgamento condenatório anterior. É preciso, primeiro, proceder à revisão da sentença condenatória, recorrendo às vias legais, mas uma vez desaparecido tal obstáculo processual, o principio da indenização não encontra mais oposição fundada na autoridade da coisa julgada" (PAuL Dvez, La responsabilité de la puissance publique, 1927, pág. 148).

"Mas, se a coisa julgada é que fixa um limite à regra geral da responsabilidade", escreve Alcino de Paula SalaZAR, "a conseqüência imediata e irrecusável do argumento 
é que essa regra geral ficará prevalecendo com relação a todos os atos que não tenham êsse caráter. Estarão, assim, fora da proteção dêsse princípio especial derrogatório daquela regra todos os atos que não constituam uma res judicata, a dizer: as decisões proferidas em processos de jurisdição voluntária e graciosa, preventivos e preparatórios, as interlocutórias, os atos de execução. Aí teremos, pois, uma larga parte da esfera de atribuições dos magistrados e dos auxiliares da justiça, envolvendo funções da maior importância, colocada fora da influência das normas reguladoras da coisa julgada" (Alcino de Paula Salazar, Responsabilidade do poder público por atos judiciais, 1941, pág. 77).

De quanto acaba de ser exposto é lícito, sem dúvida, concluir que o princípio da coisa julgada não pode ser invocado como impeditivo da aplicação, aos atos judiciais, da regra geral da responsabilidade do Estado pelas consequiências danosas da atividade de seus representantes, restringindo-se o alcance daquele princípio tão sòmente aos atos que tenham os característicos da res judicata (Alcrno de Paula Salazar, op. cit., pág. 81).

o princípio de res judicata, lembrado para irresponsabilizar o Estado por atos judiciários, é na realidade um preconceito, visto que não há nenhuma impossibilidade social em restringir ou mesmo afastar em certas hipóteses a imutabilidade da coisa julgada. $O$ conceito de coisa julgada é relativo, não acompanhando de modo absoluto a função jurisdicional (Juari Silva, Responsabilidade civil do Estado por atos jurisdicionais, em RT 351/29).

Em sintese, a coisa julgada não é um valor absoluto e, no contraste entre ela e a idéia de justiça, esta é que deverá prevalecer. Daí, não é preciso mais que um passo, no sentido de fazer subsistir a responsabilidade do Estado pelo exercício da função jurisdicional, ainda que isso implique certa restrição da amplitude do conceito de coisa 
julgada (Juari Silva, Responsabilidade civil do Estado por atos jurisdicionais, em RT 351/29).

Postos abaixo os dois argumentos dos partidários da teoria da irresponsabilidade do Estado por atos do Poder Judiciário - o argumento da soberania e o da coisa julgada -, impõe-se uma só colocação: a da responsabilidade civil do Estado, em decorrência de atos danosos dos magistrados.

A responsabilidade do poder público por atos judiciais é posição que se vai firmando, no direito universal e no direito pátrio, conforme ensinam autoridades incontestáveis.

Assinalando, com apoio em Hauriou e Orlando, "que devem ser expressamente consignados em lei os casos em que o Estado não é responsável, além dos que decorrem das providências meramente legislativas e regulamentares, enquanto não produzem efeitos executórios, ou de atos judiciários definitivos proferidos pela autoridade competente", Carlos Pôrto Carreiro admitiu, de maneira clara, a tese da responsabilidade quanto aos demais atos judiciais (Lições, 1918, págs. 245-246).

Aceitando a lição de Dreyer, o nosso Oliveira Santos esclarece "que, entre os atos que podem ocasionar a mesma responsabilidade, se devem incluir os dos juízes, os quais participam da natureza dos demais funcionários" (Direito administrativo, 1919, pág. 129).

Externando o mesmo pensamento, Olinda de Andrade põe em relêvo a tendência para uma extensão maior da responsabilidade do Estado "desde a esfera rigorosamente administrativa até a órbita doutrinária", acentuando que "a responsabilidade em matéria judiciária está consagrada nas legislações mais adiantadas" (José BonIFácıo OLINDA DE Andrade, A responsabilidade do Estado em caso de guerra, 1932, págs. 19 a 21).

Em trabalho consagrado ao tema e aqui repetidas vêzes citado, Alcino de Paula Salazar sustentou a tese, em nossos dias predominante, da responsabilidade do Estado por atos 
judiciais, chegando às seguintes conclusões: “O princípio dominante, como regra geral, em doutrina, quanto aos danos que ao patrimônio particular causa o exercício da atividade do Estado é o da plena responsabilidade dêste pelas conseqüências do funcionamento dos serviços públicos, objetivamente consideradas, compreendendo os atos de qualquer natureza que os seus agentes pratiquem, por ocasião ou por motivo da execução dos referidos serviços, sendo fundamento dessa responsabilidade a idéia solidarista da equitativa distribuição dos ônus e encargos públicos entre todos os membros da comunhão política; êste princípio geral, que está naturalmente sujeito a limitações, tem aplicação aos atos do poder judiciário, com exceção dos que constituam coisa julgada; se a decisão judicial de que não caibam recursos ordinários é ilegal e causou prejuízos, êstes não podem ser reclamados, a menos que se rescinda tal decisão por meio processual competente. Se a hipótese fôr, entretanto, de coisa soberanamente julgada, isto é, insuscetível já de recursos e de procedimento rescisório, então a exceção é irremediável. Assim, decorrido o prazo prescricional da ação rescisória da sentença, desaparece, só então, a possibilidade de se obter reparação de danos resultantes do julgado. Fora dessa hipótese estrita da coisa julgada, os atos judiciais podem acarretar a responsabilidade do Estado, sejam de natureza administrativa ou contenciosa, quando dêles resulte, segundo o critério mais preconizado, um prejuízo especial ou anormal (ALcino DE Paula Salazar, Responsabilidade do poder público por atos judiciais, 1941, págs. 95; 96; 98-99.

Em sentido oposto, Lopes Meireles, partidário da tese da irresponsabilidade do Estado por atos judiciais, escreve: "não enseja responsabilidade civil da Fazenda Pública, salvo na hipótese do artigo 630 do Código do Processo Penal, uma vez obtida a revisão criminal. Nos demais casos, as decisões judiciais, como atos de Soberania interna do Estado, não propiciam qualquer ressarcimento por 
eventuais danos que acarretem às partes ou a terceiros. Essa doutrina é tradicional no direito patrio (AMAro Cavalcanti, Pedro Lessa, Cirne lima, José de Aguiar Dias) e está remansada na jurisprudência de nossos tribunais (STF em RDA 59/335; RF 194/159; TJSP em RDA 50/239; 53/183; RT 259/127), em atenção à coisa julgada e à liberdade decisória dos magistrados, que não poderiam ficar à mercê de responsabilizações patrimoniais pela falibilidade humana de seus julgamentos. Ficará, entretanto, o juiz, individual e civilmente responsável por dolo, fraude ou retardamento injustificado de providência de seu ofício, nos expressos têrmos do artigo 121 do Código de Processo Civil, mas essa responsabilidade não se transmite nem solidariza a Fazenda Pública" (Direito administrativo brasileiro, $2^{a}{ }^{a}$ ed., 1966, págs. 538-539).

Aguiar Dias, reconhecendo embora que parte de nossa doutrina pende para a tese de irresponsabilidade do Estado por atos do Poder Judiciário, reafirma sua posição, "não obstante a persistência das idéias regalistas", mostrando que "a responsabilidade do Estado progride para um ponto de satisfação plena aos princípios solidaristas. Vai pouco a pouco perdendo terreno a tese da irresponsabilidade, para surgir em seu lugar o princípio de que o particular tem direito a ser indenizado, tôda vez que sofra um prejuízo em conseqüência do funcionamento do serviço público, pouco importando indagar se regular ou irregular, porque não se cogita de sabê-lo, mas de aplicar lògicamente o princípio de igualdade dos encargos sociais" ( $D a$ responsabilidade civil, $2{ }^{a}$ ed., 1950, vol. II, pág. 249).

Com essa manifestação, deixa Aguiar Dias bem claro o seu pensamento, sustentado, mesmo em face de nosso direito positivo, mas reconhece estar em minoria diante da corrente dominante, que aceita e defende a irresponsabilidade do Estado por atos judiciários (Da responsabilidade civil, 2. ${ }^{\text {a }}$ ed., 1950, vol. II, pág. 249). 
9. Escrevendo em 1941, Alcino de Paula Salazar resumiu a orientação jurisprudencial da época, mostrando que "a imunidade dos atos judiciais tem sido sustentada com o mesmo caráter de amplitude" (Responsabilidade do poder público por atos judiciais, pág. 66), tendo nossos tribunais acolhido inquestionàvelmente a regra da não responsabilidade por atos judiciais, embora sejam escassas as decisões relativas à questão, as quais só se referem a casos de indenização pleiteada, com prejuízo da coisa julgada, pela parte vencida na demanda, ou por acusado impronunciado em conseqüência de falta de prova da denúncia (Responsabilidade do poder público por atos judiciais, pág. 68).

No máximo, a jurisprudência admite a responsabilidađe pessoal do juiz. O Estado é irresponsável por atos judiciais danosos.

Em acórdão de 19 de agôsto de 1916, o Supremo Tribunal Federal admitia a responsabilidade do juiz, livre o erário, entretanto, do ressarcimento dos danos resultantes da sentença (Carlos Maximiliano, Comentários à Constituiç̃öo, pág. 784).

"Não tem direito a indenização do dano causado pelo processo e sim sòmente à restituição do valor dos objetos apreendidos indivíduo não pronunciado em processo-crime de contrabando por não ter ficado provado o dolo característico" (Revista $O$ Direito, 98/506).

Por sentença de 13 de julho de 1909, em ação sumária especial, instaurada para o fim de anular transferência de apólices feita pela Caixa de Amortização em cumprimento de decisão judicial, o juiz federal Pires e Albuquerque, depois Ministro do Supremo Tribunal Federal, apesar de haver decretado nulidade do processo, considerou $e x$ abundantia, que "a Fazenda não é responsável pelos danos que possam resultar de atos e decisões judiciais" (Revista $O$ Direito, 13/542).

O mesmo magistrado decidiu, em outro caso, que "a responsabilidade em que fica a Fazenda Pública pelos 
danos e prejuízos causados aos particulares pelos agentes da Administração no exercício de seus cargos não compreende os que por ventura possam resultar de atos e decisões do Poder Judiciário, que no conflito entre o Estado e particulares não representa aquêle, não promove nem defende seus interêsses como pessoa jurídica do direito civil" ( Revista $O$ Direito, 10/582. OBS. Os 3 passos da Revista $O$ Direito foram citados apud Alcino de Paula Salazar, op. cit., págs. 68-69).

Julgando a conhecida demanda promovida contra a União pelo Conde de Leopoldina para haver reparação de danos decorrentes de bens seus, realizado a requerimento do antigo Banco da República e que degenerou em falência, por decisão confirmada em última instância, o juiz corroborou a tese com a consideração de que, "em princípio, os atos do poder judiciário não obrigam a responsabilidade do Estado. Só nos casos expressamente nomeados em lei podem os atos judiciais dar lugar à responsabilidade (Revista de direito 22/527).

Ém acórdão unânime de 29 de outubro de 1926, decidiu o Supremo Tribunal Federal que "a União não é civilmente responsável pelas decisões, contenciosas ou administrativas, proferidas pelo Poder Judiciário, porque êste não é representante ou preposto dela, mas um dos órgãos da soberania nacional" (Revista de direito, 86/ 536).

Decisão de primeira instância do antigo Distrito Federal irresponsabilizou o Estado civilmente por danos causados ao particular, afirmando que "não se configura, na hipótese, um caso de responsabilidade civil do Estado, que em regra apenas responde por culpa ou negligência de seus funcionários ou prepostos e, como tais, a melhor doutrina, sufragada entre nós pela jurisprudência, não conceitue aos julgadores membros do Poder Judiciário" O Direito 97/870).

"Em sentido oposto a esta ordem de idéias", acentua Paula Salazar, "houve, entretanto, uma decisão do próprio govêrno, com apoio do Congresso Nacional, concedendo 
indenização aos herdeiros de um súdito italiano pelo valor correspondente a seguro cuja importância fôra criminosamente levantada pelo juiz do inventário" $(O$ Direito 97/660, apud Paula Salazar, op. cit., pág. 72; Cirne Lima, Princípios, $4^{\text {a }}$ ed., 1964, pág. 203; Luis M. Correia, O Estado e a obrigação de indenizar, 1930, págs. 69-70).

Neste último caso, de apropriação indébita, praticada por juiz substituto federal, a União arcou com o ônus da respectiva indenização. Súdito italiano, falecido no Amazonas, fizera um seguro de vinte contos. Abrindo-se a sucessão no juízo federal daquele Estado, o magî̉strado levantou a importância e desapareceu a seguir. Relatando o fato, J. J. SEabra, então Ministro da Justiça, na exposição de motivos que acompanhou a mensagem do Presidente Rodrigues Alves, solicitando ao Congresso a abertura do respectivo crédito, concluiu: "Contra êsse funcionário deu o Procurador Geral da República denúncia perante o Supremo Tribunal Federal e, correndo o processo seus trâmites legais, foi o referido substituto condenado nos têrmos do artigo 214 do Código Penal, mas essa condenação não desobriga o Govêrno de indenizar os herdeiros, embora tendo, contra o funcionário delinqüente, a ação regressiva para haver a importância de que aquêle magistrado criminosamente se apoderou" (Cirne Lima, Princípios, 4. ${ }^{\text {a }}$ ed., 1964, pág. 203).

10. “Tende já, porém, a jurisprudência a estabelecer a responsabilidade do Estado pelos atos de natureza graciosa ou administrativa do Poder Judiciário, como os concernentes às contas de tutelas e curatelas, arrecadação de espólios" (Cirne Lima, Princípios, 4. ${ }^{\text {a }}$ ed., 1964, págs. 202-203).

Seguindo as grandes linhas do direito universal, o direito brasileiro caminha no sentido de repelir de maneira gradativa a antiga teoria da irresponsabilidade do Estado por atos judiciais. 
O primeiro passo foi relativo ao denominado êrro judiciário; o segundo, com referência à demora na decisão dos feitos, se causada por dolo ou culpa (imprudência, imperícia ou negligência). Negligência = desídia, incúria. A seguir, por atos não jurisdicionais dos magistrados (atos da jurisdição voluntária e atos materiais do judiciário = atos administrativos do juiz).

Julgando um caso em que vieram à baila a demora e o êrro judicial, pronunciou-se o Tribunal de Justiça de S. Paulo, no sentido de que "pela demora da decisão responde o juiz correcionalmente, se causada por dolo, culpa ou desídia, não respondendo o Estado civilmente pelo êrro judicial", como diz a ementa do acórdão (JTSP em RDA $53 / 183$, acórdão de 26.8.1957).

Tratava-se de processo de inventário em que o viúvo inventariante requerera e obtiverá alvará judicial para venda de imóvel hipotecado, sem intervenção, citação ou representação de menor herdeira. Mais tarde, a herdeira, agora maior, ingressa em juizo com ação, propugnando anular a venda do imóvel. Levantou-se, no feito, o problema da demora havida no julgamento da causa pelo juiz de primeira instância, mas o Tribunal salientou que, na espécie, tal se dera não por incúria do magistrado e sim pelas falhas e deficiências do aparelhamento judiciário, impondo ao juiz um trabalho excessivo, já e em boa hora dividido por três varas.

Quanto ao pretenso êrro, os autores é que tinham agido negligentemente, aceitando como boa documentação o alvará que lhes fôra exibido, sem ao menos se darem ao trabalho de compulsar os autos do processo em que foi êle expedido, quando a êles, como compradores, é que cumpria examinar os títulos de alienante.

Se a demora, entretanto, tem causa justificada, cabe responsabilidade civil do Éstado, por falta de serviço, em caso de decisão judicial (RDA 90/140). 
Em acórdão de 9 de dezembro de 1958, pronunciou-se o Supremo Tribunal Federal pela tese da irresponsabilidade do Estado por atos judiciais, exceção feita no caso do êrro judiciário, na hipótese do artigo 630 do Código de Processo Penal, já que a figura do artigo 121 do Código de Processo Civil se refere à responsabilidade pessoal do juiz.

"Domina, pois, nesse âmbito", salienta a nota dominante do acórdão, que aceitou a tese do Ministro Relator Vilas-Boas, "o princípio da irresponsabilidade, não só em atenção à autoridade da coisa julgada, como também à lıberdade e independência dos magistrados, que se sentiriam tolhidos, a cada passo, na sua função de dizer o direito ou de resolver as graves questões administrativas que lhes são afetas, pelo temor de engendrar responsabilidade para si e para o Estado que representam. A tese dos recorrentes é avançada" (Acórdão do STF de 9.12.1958, em RDA 59/335).

"Responderá o Estado por ato do juiz, se êste cometer ato ilícito, prejudicar a parte de caso pensado. No caso de êrro judiciário, no crime, só haverá indenização se a sentença houver passado em julgado e ficar demonstrado o esfôrço da parte para esclarecer o caso" (STF em RDA $59 / 336)$.

Com efeito, “o processo passou a ser matéria de ordem pública e a justiça função do Estado. O Estado é representado pelo Juiz, figura imparcial, ativa, dinâmica, que orienta a prova, fiscaliza, impede a alicantina, vela pela economia de tempo, coibe os abusos, norteia as causas com o fito de descobrir a verdade para a realização da justiça integra" (Acórdão do Tribunal do Estado do Rio, em Revista Trimestral de Jurisprudência 10/64).

Em acórdão de 21 de junho de 1966, o Supremo Tribunal Federal teve ocasião de examinar por todos os ângulos o problema da responsabilidade do Estado em decorrência de ato judicial moroso. 
Culpa do juiz? Falha do serviço? Culpa da parte?

Concluíu o Supremo Tribunal Federal, contra os votos dos Ministros Aliomar Baleeiro e Adalício Nogueira, que "a atividade jurisdicional do Estado, manifestação de sua soberania, só pode gerar responsabilidade civil, quando efetuada com culpa, em detrimento dos preceitos reguladores da espécie" (Acórdão de 21.6.1966 do STF em RF $220 / 105)$.

Tratava-se de pessoa que acionara o Estado porque a alegada desídia do juiz fizera com que prescrevesse sua queixa-crime oferecida contra jornalista que a injuriara na imprensa local; a despeito da diligência tenaz de seu advogado, juiz e serventuários teriam sido morosos em marcar audiências e praticar os atos processuais. Logo, o Estado não cumprira sua finalidade e dever de prestar os serviços de justiça, pelo que deveria indenizá-lo dos honorários, custas e despesas inùtilmente feitas.

Procurou eximir-se o Estado, argumentando não ser responsável por atos dos membros do Poder Judiciário, tendo o juiz de primeira instância acolhido a ilegitimidade passiva dessa pessoa de direito público. Pronunciou-se a segunda instância que julgou improcedente a ação por não estarem caracterizados dolo e culpa do juiz criminal, assoberbado de trabalho, pois atendia a duas comarcas, razão pela qual ocorrera justo motivo de retardamento, o que, no caso, até se equipararia à fôrça maior.

Apelou o recorrente, argüindo que responsabilizara não o juiz, mas o Estado, porque não providenciara nem equipara eficientemente o serviço da justiça, evitando seu congestionamento ou provendo substituições e outras medidas curiais.

Confirmou o acórdão a sentença recorrida, porque ficou provado a inocorrência de culpa do juiz, esmagado pelo trabalho de duas comarcas por impedimento do titular destas. Se o Código de Processo Civil escusa o juiz (artigo 
121, II), escusa também o Estado. Ora, excesso de trabalho é "justo motivo" para a demora no julgamento do feito, conforme aquêle inciso do Código de Processo Civil.

Recorreu o autor extraordinàriamente ao Supremo Tribunal Federal, que conheceu do recurso, mas lhe negou provimento, vencidos os Ministros Aliomar Baleeiro e Adalício Nogueira.

Argumentou Aliomar Baleeiro que não se tratava, na espécie, de apreciar o justo motivo da morosidade do juiz, mas de apurar a responsabilidade do Estado em não prover adequadamente o bom funcionamento da justiça, ocasionando, por sua omissão dos recursos materiais e pessoais adequados, os estorvos ao pontual cumprimento dos deveres de seus juízes. Nem poderia ignorar essas dificuldades, porque, como consta das duas decisões contrárias ao recorrente, estando uma das comarcas acéfala, o que obrigou o juiz a atendê-la, sem prejuízo da sua própria - ambas congestionadas de serviço - a Comissão de Disciplina declarou-se em regime de exceção, ampliando os prazos. Se o Estado responde, segundo antiga e iterativa jurisprudência, pelos movimentos multitudinários, ou pelo "fato das coisas" do serviço público, independentemente de culpa de seus agentes, com maior razão deve responder por sua omissão ou negligência em prover eficazmente ao serviço da Justiça, segundo as necessidades e reclamos dos jurisdicionados, que lhes pagam impostos e taxas judiciárias específicas, para serem atendidos (RF 220/105).

No caso, há certeza da lesão e da imputabilidade da causa dela à omissão do Estado, como gerador único do prejuizo. Ou o juiz teve culpa, por desidioso, ou fez tudo quanto humanamente poderia fazer e não venceu a passividade do Estado em primeiros obstáculos. O probíema transborda do direito civil para o direito administrativo, dentro do qual os doutores proclamam a responsabilidade do Estado em tais circunstâncias, independentemente da culpa de seus agentes. Êle se eximiria se provasse que o 
prejuizo ocorreu, ou ocorreria, ainda que tivesse empregado todos os meios adequados para citá-lo. Aí, sim, se poderia falar em fôrça maior. Responde, pois, pela omissão, causa eficiente do prejuízo, como responderia pela ação, se ela fôsse a origem da lesão. Se não foi desidioso o juiz, foram desidiosas as autoridades superiores, inclusive os órgãos dos três podêres do Estado, pela situação calamitosa de desordem em que submergiu o direito do autor, usuário legítimo do serviço público judiciário, para o que pagou a taxa judiciária e os selos dos autos, além de impostos. Já se tem condenado o Estado até pelos atos de terceiros que exerceram autoridade de fato em seu nome e mais expressivas são as condenações resultantes anônimamente daquilo que os franceses chamam $d u$ fait des choses" (RF 220/105-106).

Idêntica a posição de Adalício Nogueira, também vencido, que, perfilhando a teoria de culpa administrativa, condenou o Estado à reparação dos danos causados pela demora: "O Estado não acionou, convenientemente, a engrenagem do serviço público judiciário. Não proporcionou à parte a prestação jurisdicional a que estava obrigado. Houve falta do serviço público. Não precisa atingir as alturas do risco, que é o cimo culminante da doutrina objetiva, para decretar-lhe a responsabilidade. Basta-me invocar o princípio da culpa administrativa, ocorrente na espécie e que não se confunde com a culpa civil, porque procede, precisamente, do mau funcionamento de um serviço" ( $\mathrm{RF} 220 / 107-108$ ).

Interessante caso concernente à responsabilidade civil do Estado por omissão de magistrado foi suscitado perante a Quinta Câmara Civil do TJSP, ao dar provimento ao agravo n. ${ }^{\circ} 158.907$ contra decisão de magistrado de primeira instância que teria retardado cumprimento de ordem de habeas corpus emanado das Câmaras Criminais Conjuntas do Egrégio Tribunal de Justiça. Deu-se provimento ao agravo, ordenando-se fôsse prosseguido o fẹito a fim 
de apurar-se o porque da inércia do órgão 'judicante, cuja conseqüência foi a de ter ficado prêso o réu por tempo superior a um mês (RF 225/154).

11. A responsabilidade do Estado por atos judiciais é espécic do gênero responsabilidade do Estado por atos decorrentes do serviço público, porque o ato judicial é, antes de tudo, um ato público, ato de pessoa que exerce o serviço público judiciário.

Equipara-se o magistrado ao funcionário público para efeitos de responsabilidade e o serviço de justiça ao serviço público, numa relação de gênero a espécie (público e judicial).

Por sua vez, no âmbito do Poder Judiciário, editam-se atos judiciais jurisdicionais, contenciosos e voluntários, e atos judiciais não jurisdicionais, ou atos administrativos materiais, editados pelo Judiciário, agora nas vestes de administrador.

Os atos materiais, praticados pelo Poder Judiciário, tais como, nomeações, demissões, concessão de licenças, férias, atos de correição, se causam dano aos administrados, empenham a responsabilidade civil do Estado, de acôrdo com o regime jurídico comum da responsabilidade pública, equacionada em têrmos publicistivos, de responsabilidade do Estado por atos de seus funcionários.

Os atos da chamada jurisdição voluntária, tais como os referentes às contas de tutelas, curatelas, arrecadações de espólios, se causam prejuízo aos administrados, acarretam a responsabilidade do E'stado, conforme a orientação da jurisprudência (RT 135/680).

Os atos típicos do Poder Judiciário, atos formais, orgânicos — os atos jurisdicionais -, que culminam com a prolação da sentença judiciária, devem ser encarados em dois momentos de seu processamento, ou seja, durante o dinamismo processual e no instante em que se profere a sentença. 
Se o período que antecede a prolação da sentença judiciária se caracteriza pela morosidade, trazendo prejuízo à parte, tem-se de considerar as razões do retardamento do feito; se a sentença traz em si um êrro judiciário, é preciso considerar a natureza da sentença, se penal ou cível, para avaliar o tipo de dano, patrimonial, moral, ou moral-patrimonial.

A chave da questão é dano e o nexo causal entre a pessoa jurídica de direito público a quem se atribui o prejuízo e o prejuízo causado. Houve dano, haverá indenização, exceto nos casos das excludentes típicas da responsabilidade, como a fôrça maior, a culpa da vítima, o estado de necessidade, o ato de terceiro.

Não militam a favor da irresponsabilidade do Estado por atos judiciais, nem o argumento da soberania, nem o da incontrastabilidade da coisa julgada, em primeiro lugar, porque soberano só o Estado, jamais êste ou aquêle poder, tomado de per si, em segundo lugar, porque a coisa julgada pode ser atacada pela rescisória ou pela revisão.

Pelos prejuízos que os atos judiciais causem aos administrados responderá o Estado, quer se prove a culpa ou dolo do magistrado, quer os danos sejam ocasionados pelo serviço de administração da justiça, que é, antes de tudo, um serviço público do Estado.

12. Sustentamos, neste artigo, a tese da responsabilidade do Estado por atos judiciais, em sentido amplo, fundamentando-nos em princípios publicísticos, que informam o moderno direito administrativo, dando como válidas para o sistema jurídico brasileiro as seguintes proposições:

a) A responsabilidade do Estado por atos judiciais é espécie do gênero responsabilidade do Estado por atos decorrentes do serviço público.

b) As funções do Estado são funções públicas, exercendo-se pelos três podêres. 
c) O magistrado ẻ órgão do Estado. Ao agir, não age em seu nome, mas em nome do Estado, do qual é representante.

d) O serviço público judiciário pode causar dano às partes que vão a juízo pleitear direitos, propondo ou contestando ações (cível). Ou na qualidade de réus (crime).

e) 0 julgamento, quer no crime, quer no cível, pode consubstanciar-se no êrro judiciário, motivado pela falibilidåde humana na decisão.

f) Por meio dos institutos rescisório e revisionista é possível atacar-se o êrro judiciário, de acôrdo com as formas e modos que a lei prescrever, mas se o equívoco já produziu danos, cabe ao Éstado o dever de repará-los.

g) Voluntário ou involuntário, o êrro de conseqüências danosas exige reparação, respondendo o Estado civilmonte pelos prejuízos causados. Se o êrro foi motivado por falta pessoal do órgão judicante, ainda assim o Estado responde, exercendo a seguir o direito de regresso sôbre o causador do dano, por dolo ou culpa.

h) Provado o dano e o nexo causal entre êste e o ór são judicante, o Estado responde patrimonialmente pelos prejuizos causados, fundamentando-se a responsabilidade do poder público, ora na culpa administrativa, o que envolve também a responsabilidade pessoal do juiz, ora no acidente administrativo, o que exclui o julgador, mas empenha o Estado, por falha técnica do aparelhamento judiciário, ora no risco integral, o que empenha também o Estado, de acôrdo com o princípio solidarista dos ônus e cneargos públicos. 